\title{
Hematological responses of tambaqui Colossoma macropomum (Serrassalmidae) fed with diets supplemented with essential oil from Mentha piperita (Lamiaceae) and challenged with Aeromonas hydrophila
}

\author{
Suzana Cardoso RIBEIRO ${ }^{1}$, Antonielson Silva CASTELO², Bruna Marjara Picanço da SILVA², Andreza da \\ Silva CUNHA², Aldo Aparecido PROIETTI JÚNIOR ${ }^{3}$, Eliane Tie OBA-YOSHIOKA²* \\ 1 Universidade Federal do Amapá. Programa de Pós-Graduação em Biodiversidade Tropical. Rodovia Juscelino Kubitschek, km 02, Macapá, AP, Brasil; \\ 2 Embrapa Amapá, Laboratório de Aquicultura e Pesca, Rodovia Juscelino Kubitschek, km 05, no. 2.600, Bairro Universidade, Macapá, AP, Brasil; \\ ${ }^{3}$ Universidade Federal do Amapá, Laboratório de Microbiologia Aplicada. Rodovia Juscelino Kubitschek, km 02, Macapá, AP, Brasil; \\ * Corresponding author: eliane.yoshioka@embrapa.br.
}

\begin{abstract}
In fish farmings, diseases can be reduced by using immunostimulants. The aim of this study was to evaluate the immunostimulant potential of Mentha piperita in tambaqui fed with 0, 0.5, 1.0 and 1.5\% of oil per kg of commercial fish feed. The fish were inoculated with Aeromonas hydrophila to challenge them. Hematological and biochemical parameters were determined after 30 days of feeding and seven days after the challenge. There was no mortality and $M$. piperita oil did not influence fish production parameters. However, blood hemoglobin concentration $(\mathrm{Hb})$ increased in the fish fed with 0.5 and $1.5 \%$ of oil per kg of diet; albumin increased in those fed with 1.0\%; cholesterol increased in all groups with oil; and triglycerides increased in those fed with $0.5 \%$. After the bacterial challenge, the fish showed decreases in $\mathrm{Hb}$ when fed with diet enriched with $1.5 \%$ oil per $\mathrm{kg}$ of diet, in mean corpuscular volume with $1.0 \%$ and in mean corpuscular hemoglobin concentration with 0 and $1.5 \%$. Protein levels increased in groups with 0 and $1.5 \%$ of oil and albumin when fed with 0 and $1.0 \%$; cholesterol levels increased in the control group; and high levels of triglycerides were observed in the groups with $0,0.5$ and $1.5 \%$. Thus, $M$. piperita essential oil promoted hematological alterations in tambaqui and can be recommended in diets containing up to $1.0 \%$ per $\mathrm{kg}$, because of the minimal physiological modifications caused. However, additional studies are necessary to obtain more information regarding to the physiological effects of this immunostimulant.
\end{abstract}

KEYWORDS: Immune system; natural product; bacterial challenge; biochemistry.

\section{Respostas hematológicas de tambaqui Colossoma macropomum (Serrassalmidae) alimentado com dietas suplementadas com óleo essencial de Mentha piperita (Lamiaceae) e desafiados com Aeromonas hydrophila}

\section{RESUMO}

Em pisciculturas, doenças podem ser minimizadas com o uso de imunoestimulantes. O objetivo deste estudo foi avaliar o potencial imunoestimulante do óleo essencial de Mentha piperita na dieta de tambaqui com dietas contendo 0; 0,5; 1,0; $1,5 \%$ de inclusão do óleo por kg de ração comercial para peixes. Os tambaquis foram desafiados com a bactéria Aeromonas hydrophila. Hematologia e bioquímica dos tambaquis foram determinados após 30 dias de alimentação e sete dias do desafio. Não houve mortalidade dos peixes durante o experimento, sendo que o óleo náo influenciou os parâmetros produtivos dos peixes. Entretanto, a concentraçáo de hemoglobina $(\mathrm{Hb})$ aumentou em peixes alimentados com 0,5 e 1,5\% de óleo por kg de dieta; a albumina aumentou em 1,0\%; o colesterol aumentou em todos os grupos com óleo; e triglicérides em $0,5 \%$ por $\mathrm{kg}$ de dieta. Após desafio bacteriano ocorreram diminuiçóes da $\mathrm{Hb}$ nos peixes alimentados com 1,5\% de óleo; do volume corpuscular médio com 1,0\%; e da concentração de hemoglobina corpuscular média com 0 e 1,5\%. Níveis aumentados de proteína nos grupos 0 e 1,5\%; da albumina em 0 e 1,0\%; do colesterol no controle; e dos triglicérides em 0, 0,5 e 1,5\% de óleo na dieta. Assim o óleo essencial de $M$. piperita na dieta promoveu alteraçôes hematológicas e pode ser recomendado seu uso em inclusões de até $1,0 \%$ por $\mathrm{kg}$ da dieta de tambaqui, devido às mínimas alterações fisiológicas causadas. Entretanto, estudos adicionais são necessários, de modo a obter informaçóes sobre os efeitos fisiológicos deste imunoestimulante.

PALAVRAS-CHAVE: Sistema imune; produto natural; desafio bacteriano; bioquímica. 


\section{INTRODUCTION}

Use of antibiotics and chemotherapeutics for treatment and prophylaxis in aquaculture can have many negative impacts, and this has led to a search for alternative products, such as probiotics and immunostimulants from plants (Logambal et al. 2000; Biller-Takahashi and Urbinati 2014; Mehana et al. 2015). Evaluation of the use of phytochemicals in aquaculture is a relatively new research area, but this has been generating promising results (Anderson 1992; Citarasu 2010; Biller-Takahashi and Urbinati 2014).

In Lates calcarifer, Allium sativum causes hematological changes and improves both oxygen transport and the immune response (Talpur and Ikhwanuddin 2012); Ocimum basilicum (basil) increases the resistance of Cyprinus carpio against infection by Aeromonas hydrophila (Amirkhani and Firouzbaksh 2015); and diets containing Mangifera indica (mango) kernel increase the resistance of L. rohita (Sahu et al. 2007). Astaxanthin, a carotenoid pigment produced by some algae, and bacteria, was used at concentrations of 50 and 100 $\mathrm{mg} \mathrm{kg}^{-1}$ in the diet of common carp C. carpio and, was found to stimulate growth, hematological alterations, immune response and specific bacterial disease protection (Jagruthi et al. 2014).

Aeromonas hydrophila is among the pathogenic bacteria that have been correlated with high levels of fish mortality, on fish farms throughout the world over the last decade, thus resulting in huge economic losses (Monette et al. 2006). This bacterium is frequently associated with hemorrhagic septicemia, fin erosion and abdominal cavity distension, among other pathological conditions (Paniagua et al. 1990; Joseph and Carnahan 1994; Silva et al. 2012). The use of antibiotics as a preventive measure has been questioned (Kaskhedikar and Chhabra 2010), because this alters the intestinal microbiota and induces bacterial resistance through nonspecific defense mechanisms (Sakai 1999). In this manner, immunostimulants have shown beneficial effects for fish farms, not only as an alternative for disease management, but also for promoting growth and achieving improvements of both specific and the nonspecific the immune system (Harikrishnan and Balasundaram 2008; Harikrishnan et al. 2009 a,b; Mehana et al. 2015).

The tambaqui is a native fish species of the Amazon region and is farmed in many regions of Brazil. It successfully adapts to captive farming, because of good feed conversion, good growth, easy handling and good availability of juveniles (Val et al. 2000; Izel and Melo 2004; Tavares-Dias 2011).

Thus, the present study aimed to evaluate the hematological responses of tambaqui after being fed with a diet that included essential oil from $M$. piperita, as an immunostimulant, and after application of a bacterial challenge protocol using $A$. hydrophila, in order to evaluate the immunocompetence and disease resistance of this fish species, consequent to the use of this immunostimulant in its diet.

\section{MATERIALS AND METHODS}

This experiment was authorized by Embrapa (proc. no. 02001.002877/2014-64) and IBAMA (no. 002/2008), in accordance with current Brazilian legislation. Tambaqui specimens were acquired from local fish farms at an average weight of $36.0 \pm 7.7 \mathrm{~g}$ and were transported to Embrapa Amapá, in Macapá (AP). They were randomly distributed to 12 water tanks (20 fish per tank) with a capacity of $500 \mathrm{~L}$. These tanks were connected to a biological filter, with continuous water flow and constant aeration, so as to maintain constancy of physicochemical variables: dissolved oxygen (DO) 7.32 $\pm 0.58 \mathrm{mg} \mathrm{L}^{-1}$ (HI 9146, HANNA, Woonsocket, RI, USA); pH $7.46 \pm 0.46$ (Ecosense pH 100, YSI, China); temperature $27.78 \pm 0.52{ }^{\circ} \mathrm{C}$ (Ecosense pH 100, YSI, China); ammonia $0.4 \pm 0.1 \mathrm{mg} \mathrm{L}^{-1}$ (HI 96715C, HANNA, Woonsocket, USA, $\mathrm{RI}$,); alkalinity $26.43 \pm 14.3 \mathrm{mg} \mathrm{CaCO}_{3} \mathrm{~L}^{-1}$ (Acqua Supre, Acqua Análises, Jundiaí, SP, Brazil); and hardness $16.67 \pm$ $8.56 \mathrm{mg} \mathrm{CaCO}_{3} \mathrm{~L}^{-1}$ (Acqua Supre, Acqua Análises, Jundiaí, SP, Brazil). The fish were kept under laboratory conditions for 20 days and were fed with commercial fish food containing $32 \%$ crude protein (CP). Tank cleaning was performed every three days to remove excess food and feces.

Four diets were tested: $0 \%$ or control, without inclusion of the oil; $0.5 \%$ : inclusion of $0.5 \% ; 1.0 \%$ : inclusion of $1.0 \%$; and $1.5 \%$ : inclusion of $1.5 \%$ of the essential oil from M. piperita per kg of commercial fish food. The treatments were performed in triplicate, such that the fish were fed until apparent satiety, twice daily (8:00 and 16:00 hours). The $M$. piperita essential oil samples were obtained from the Medicinal Plant Laboratory, Embrapa Western Amazon (Manaus, AM). The $M$. piperita essential oil presented the following chemical components: alpha-pinene (1.1\%), betapinene $(1.9 \%)$, myrcene $(1.1 \%)$, p-cymene $(4.6 \%)$, limonene (3.1\%), menthone (18.2\%), iso-menthone (13.4\%), menthol (30.8\%), 4-terpineol (1.5\%), pulegone (13.7\%) and menthyl acetate $(9.7 \%)$. To incorporate the essential oil into the diet, solutions for each level of inclusion were prepared using cereal alcohol (Dairiki et al. 2013), adding $M$. piperita essential oil at the necessary quantity. These solutions were sprayed manually onto commercial fish food (32\% CP and $4 \mathrm{~mm}$ ration size) to be incorporated into it. The food was then dried at room temperature for 24 hours before its use in feeding the fish.

After the 30-day feeding period, blood collection was performed by caudal vein puncture in fifteen fish from each treatment, using sodium heparin anticoagulant, after they had previously been anesthetized using $0.1 \%$ benzocaine (Sigma-Aldrich, St. Louis, MO, USA). The blood samples collected were kept on ice to obtain the hematocrit $(\mathrm{Ht})$, 
hemoglobin concentration $(\mathrm{Hb})$ and erythrocytes count (Er); and to calculate Wintrobe's hematimetric index: mean corpuscular volume (MCV), mean corpuscular hemoglobin $(\mathrm{MCH})$ and mean corpuscular hemoglobin concentration (MCHC), in accordance with Ranzani-Paiva et al. (2013). The remaining blood was centrifuged at $13.709 \mathrm{~g}$ for $5 \mathrm{~min}$ (Centrifuge 5424, Eppendorf, Hamburg, Germany). The plasma samples thus obtained were used to determine the concentrations of glucose, protein, albumin, cholesterol and triglycerides using colorimetric kits (Bio Tecnica ${ }^{\circ}$, Varginha, MG, Brazil), and absorbance readings were performed using a spectrophotometer (Biospectro SP-220; Curitiba, PR, Brazil).

After blood sample collection, the remaining tambaqui specimens were infected with $A$. hydrophila (ATCC 7966) (Seshadri et al. 2006). For this, the fish were intraperitoneally inoculated with $A$. hydrophila at a concentration of $1.5 \times 10^{8}$ UFC $\mathrm{mL}^{-1}$. For 15 days, these fish were observed with regard to mortality and clinical signs of occurrences of aeromonosis, such as hemorrhagic petechiae, abdominal cavity distension, ulcerative injuries on the body surface, fin hemorrhage, fish isolated from the shoal and blackish coloring, among others. Seven days after inoculation of the bacterium, blood collection was performed on nine fish per treatment.

The results obtained from the hematological and biochemical evaluations on the fish, after they had been fed with diets containing different levels of $M$. piperita essential oil $(0,0.5,1.0$ and $1.5 \%)$, and after bacterial challenge, were statistically compared using parametric and nonparametric tests to find out which groups were different between each other $(\mathrm{P}<0.05)$, after applying the normality test $(\mathrm{Zar} 2010)$.

\section{RESULTS}

The bacterial challenge with $A$. hydrophila at a concentration of $1.5 \times 10^{8} \mathrm{UFC} \mathrm{mL} \mathrm{mL}^{-1}$, performed on tambaqui of the present study, did not produce any clinical signs of aeromonosis (from viewing the external appearance of the fish) and there were no deaths.

The concentrations of essential oil from $M$. piperita that were tested in the diets, in the present study, did not influence the fish production performance parameters, since there were no significant differences in weight gain, although there was a tendency towards reduction in the group fed with $1.0 \%$ of oil in the diet (Table 1).

The hemoglobin concentration in tambaquis fed with diets containing 0.5 and $1.5 \%$ of $M$. piperita essential oil increased significantly in relation to the other diets. After experimental bacterial infection with $A$. hydrophila, a decrease in $\mathrm{Hb}$ was observed among the fish fed with $1.5 \%$ of oil in the $\operatorname{diet}(\mathrm{P}<0.05)$. The inclusion of the essential oil did not change the MCV of the tambaquis, but the MCV decreased after the bacterial challenge in the group fed with the diet that included $1.0 \%$ of $M$. piperita oil. Feeding with $M$. piperita oil did not alter the MCHC values, but after the bacterial challenge with $A$. hydrophila, these values decreased in the control fish group (0\%) and the group with $1.5 \%$ of oil in the diet (Table 2).

The plasma glucose concentrations in the tambaquis fed with diets containing $M$. piperita oil did not show any alterations, even after the bacterial challenge. The plasma protein concentration in the tambaquis only showed an alteration after the bacterial challenge, with increased values in the groups with 0 and $1.5 \%$ of the essential oil in the diet. Increased levels of albumin were found in the fish fed with diets containing 0 and $1.0 \%$ of the oil after the bacterial challenge.

The plasma cholesterol levels increased in all the fish fed with diets containing essential oil (from 0.5 to $1.5 \%$ inclusion per $\mathrm{kg}$ of diet). After the bacterial challenge, only the control group presented a significant increase in cholesterol levels. The plasma triglyceride values were lowest in the fish fed with diets enriched with $0.5 \%$ of essential oil. However, after the challenge with $A$. hydrophila, the fish fed with $0,0.5$ and $1.5 \%$ of oil in the diet presented significantly increased values.

\section{DISCUSSION}

The inclusion levels of 0.5 to $1.5 \%$ of $M$. piperita essential oil used in the diet for the tambaquis did not promote weight gain. This was contrary to the study by Talpur (2014), who reported body weight gain in $L$. calcarifer, with levels of 2 to $5 \mathrm{~g}$ of $M$. piperita leaves per $\mathrm{kg}$ of food. Moreover, this author reported that there was a good feed conversion rate with higher amounts of $M$. piperita in the diet, coming from this plant's characteristic of stimulating fish appetite. According to Sharafi et al. (2010), M. piperita essential oil presents very important antioxidant properties and is appropriate for use in food, cosmetics and medicine. Thus, it has been found that the form of use of the plant, i.e. its leaves (Talpur 2014) or its essential oil (Sharafi et al. 2010; present study), can influence the acceptance of the diet by fish and the action of its bioactive components.

The coefficient of variation among the tambaquis after feeding on $M$. piperita essential oil was higher $(57 \%)$ when fed with diets containing $0.5 \%$ of the essential oil, in relation to the other groups. The coefficient of variation was $29 \%$ for fish fed without essential oil; 39\% for fish fed with $1.0 \%$ of oil in the diet; and $40 \%$ in fish fed with $1.5 \%$ oil in the diet. This may indicate that the acceptance of diets with inclusion of this oil was not good among the fish, especially among those fed with diets containing $0.5 \%$ of oil in the diet. The fish that may have accepted the diet best were possibly those fed with $1.0 \%$ of the oil, because the FCR was 1.66 (Table 1). However, in terms of performance, the fish with the best FCR were those that received the diet without essential oil. 
Table 1. Initial and final weight, weight gain (mean \pm standard deviation) and feed conversion rate (FCR) of tambaqui groups fed with diets containing $0,0.5$, 1.0 and $1.5 \%$ of Mentha piperita essential oil per $\mathrm{kg}$ of diet for 30 days.

\begin{tabular}{ccccc}
\hline & \multicolumn{4}{c}{ Inclusion levels of M. piperita essential oil } \\
\cline { 2 - 5 } & $0 \%$ & $0.5 \%$ & $1.0 \%$ & $1.5 \%$ \\
\hline Initial weight $(\mathrm{g})$ & $20.35 \pm 4.84$ & $20.74 \pm 4.64$ & $20.19 \pm 4.74$ & $20.10 \pm 3.33$ \\
\hline Final weight $(\mathrm{g})$ & $75.81 \pm 22.39$ & $63.56 \pm 36.09$ & $59.13 \pm 23.03$ & $68.74 \pm 27.74$ \\
\hline Weight gain (g) & $58.15 \pm 19.21$ & $44.20 \pm 34.54$ & $38.94 \pm 22.69$ & $48.64 \pm 28.36$ \\
FCR & 1.07 & 1.42 & 1.66 & 1.28 \\
\hline
\end{tabular}

There were no statistical differences $(P>0.05)$.

Table 2. Hematocrit $(\mathrm{Ht})$, hemoglobin concentration $(\mathrm{Hb})$, erythrocytes count (Er) and hematocrit indices (mean corpuscular volume, MCV; mean corpuscular hemoglobin, $\mathrm{MCH}$ and mean corpuscular hemoglobin concentration, $\mathrm{MCHC}$ ) (mean \pm standard deviation) of tambaqui groups fed with diets containing $0,0.5$, 1.0 and $1.5 \%$ of Mentha piperita essential oil per $\mathrm{kg}$ of diet for 30 days, before Aeromonas hydrophila challenge and seven days afterwards.

\begin{tabular}{|c|c|c|c|c|}
\hline & \multicolumn{4}{|c|}{ Inclusion levels of $M$. piperita essential oil } \\
\hline & $0 \%$ & $0.5 \%$ & $1.0 \%$ & $1.5 \%$ \\
\hline & \multicolumn{4}{|c|}{ Before bacterial challenge } \\
\hline $\mathrm{Ht}(\%)$ & $17.54 \pm 3.73 a$ & $19.75 \pm 3.36 \mathrm{a}$ & $18.20 \pm 4.16 a$ & $19.65 \pm 2.22 \mathrm{a}$ \\
\hline $\mathrm{Hb}\left(\mathrm{g} \mathrm{dL}^{-1}\right)$ & $5.71 \pm 1.27 \mathrm{~b}$ & $6.83 \pm 0.98 \mathrm{a}$ & $6.30 \pm 1.32 b$ & $7.76 \pm 0.62 \mathrm{a}$ \\
\hline $\operatorname{Er}\left(x 10^{6} \mu L^{-1}\right)$ & $1.04 \pm 0.34 a$ & $0.93 \pm 0.25 a$ & $0.94 \pm 0.35 a$ & $1.04 \pm 0.34 a$ \\
\hline MCV (fL) & $181.09 \pm 62.41 \mathrm{a}$ & $192.20 \pm 58.43 a$ & $169.25 \pm 41.52 \mathrm{a}$ & $181.09 \pm 62.41 \mathrm{a}$ \\
\hline $\mathrm{MCH}\left(\mathrm{g} \mathrm{dL}^{-1}\right)$ & $70.33 \pm 14.37 a$ & $65.97 \pm 15.98 a$ & $67.24 \pm 10.74 a$ & $65.63 \pm 10.29 a$ \\
\hline \multirow[t]{2}{*}{$\mathrm{MCHC}\left(\mathrm{g} \mathrm{dL}^{-1}\right)$} & $42.46 \pm 16.76 a$ & $34.33 \pm 8.33 a$ & $39.29 \pm 12.16 a$ & $42.93 \pm 13.68 \mathrm{a}$ \\
\hline & \multicolumn{4}{|c|}{ After bacterial challenge } \\
\hline $\mathrm{Ht}(\%)$ & $20.05 \pm 2.97 a$ & $19.94 \pm 3.08 a$ & $16.28 \pm 4.53 a$ & $18.50 \pm 3.31 a$ \\
\hline $\mathrm{Hb}\left(\mathrm{g} \mathrm{dL}^{-1}\right)$ & $5.29 \pm 2.26 a$ & $5.94 \pm 1.64 a$ & $4.60 \pm 2.21 a$ & $4.29 \pm 1.79 \mathrm{a}^{*}$ \\
\hline $\operatorname{Er}\left(x 10^{6} \mu \mathrm{L}^{-1}\right)$ & $0.66 \pm 0.18 \mathrm{a}$ & $0.71 \pm 0.22 \mathrm{a}$ & $0.89 \pm 0.37 a$ & $1.21 \pm 0.24 a$ \\
\hline MCV (fL) & $271.90 \pm 176.32 a$ & $248.37 \pm 139.73 a$ & $107.85 \pm 38.73 a^{*}$ & $187.59 \pm 106.33 a$ \\
\hline $\mathrm{MCH}\left(\mathrm{g} \mathrm{dL}^{-1}\right)$ & $95.82 \pm 27.79 a$ & $75.59 \pm 22.23 a b$ & $51.26 \pm 10.65 b$ & $60.71 \pm 14.19 b$ \\
\hline $\operatorname{MCHC}\left(\mathrm{g} \mathrm{dL}^{-1}\right)$ & $35,72 \pm 16,37 a^{*}$ & $35,95 \pm 18,66 a$ & $46,70 \pm 18,03 a$ & $36,32 \pm 18,80 a^{*}$ \\
\hline
\end{tabular}

Small different letters in the same row indicate statistically significant differences $(P<0.05)$ among essential oil inclusion levels; asterisk ( $\left.{ }^{\star}\right)$ indicates statistically significant differences $(P<0.05)$ between values before and after bacterial challenge. fL means femtoliter, i.e. a volume measurement unit equivalent to $10^{-15}$ liter or to $1 \mu \mathrm{m}^{3}$.

Table 3. Glucose, protein, albumin, cholesterol and triglycerides plasma levels (mean \pm standard deviation) of tambaqui groups fed with diets containing 0 , $0.5,1.0$ and $1.5 \%$ of Mentha piperita essential oil per $\mathrm{kg}$ of diet for 30 days, before Aeromonas hydrophila challenge and seven days afterwards.

\begin{tabular}{ccccc}
\hline & \multicolumn{4}{c}{ Inclusion levels of M. piperita essential oil } \\
\cline { 2 - 5 } & $0 \%$ & $0.5 \%$ & $1.0 \%$ & $1.5 \%$ \\
\hline Glucose $\left(\mathrm{mg} \mathrm{dL}^{-1}\right)$ & $79.25 \pm 22.50 \mathrm{a}$ & $87.85 \pm 24.93 \mathrm{a}$ & $85.48 \pm 20.80 \mathrm{a}$ & $76.49 \pm 18.02 \mathrm{a}$ \\
\hline Protein $\left(\mathrm{g} \mathrm{dL}^{-1}\right)$ & $3.07 \pm 0.59 \mathrm{a}$ & $2.81 \pm 0.81 \mathrm{a}$ & $2.68 \pm 0.54 \mathrm{a}$ & $2.50 \pm 0.45 \mathrm{a}$ \\
\hline Albumin $\left(\mathrm{g} \mathrm{dL}^{-1}\right)$ & $0.94 \pm 0.23 \mathrm{a}$ & $0.89 \pm 0.17 \mathrm{a}$ & $0.95 \pm 0.17 \mathrm{a}$ & $1.00 \pm 0.23 \mathrm{a}$ \\
\hline Cholesterol $\left(\mathrm{mg} \mathrm{dL}^{-1}\right)$ & $62.85 \pm 9.83 \mathrm{~b}$ & $83.78 \pm 16.71 \mathrm{a}$ & $86.64 \pm 39.92 \mathrm{a}$ & $98.93 \pm 18.61 \mathrm{a}$ \\
\hline Triglycerides $\left(\mathrm{mg} \mathrm{dL}^{-1}\right)$ & $272.96 \pm 29.93 \mathrm{a}$ & $224.76 \pm 54.30 \mathrm{~b}$ & $271.49 \pm 60.49 \mathrm{a}$ & $286.17 \pm 45.21 \mathrm{a}$ \\
\hline & & \multicolumn{4}{c}{ After bacterial challenge } & \\
\hline Glucose $\left(\mathrm{mg} \mathrm{dL}^{-1}\right)$ & $79.50 \pm 7.21 \mathrm{a}$ & $76.81 \pm 20.55 \mathrm{a}$ & $74.61 \pm 16.74 \mathrm{a}$ & $81.89 \pm 10.92 \mathrm{a}$ \\
\hline Protein $\left(\mathrm{g} \mathrm{dL}^{-1}\right)$ & $3.44 \pm 0.73 \mathrm{a}^{*}$ & $3.14 \pm 0.42 \mathrm{~b}$ & $3.30 \pm 0.25 \mathrm{a}$ & $3.23 \pm 0.36 \mathrm{a}^{*}$ \\
Albumin $\left(\mathrm{g} \mathrm{dL}^{-1}\right)$ & $1.09 \pm 0.10 \mathrm{~b}^{*}$ & $0.98 \pm 0.20 \mathrm{~b}$ & $1.48 \pm 0.14 \mathrm{a}^{*}$ & $0.97 \pm 0.12 \mathrm{~b}$ \\
Cholesterol $\left(\mathrm{mg} \mathrm{dL}^{-1}\right)$ & $137.37 \pm 11.80 \mathrm{a}^{*}$ & $127.58 \pm 48.54 \mathrm{a}$ & $114.65 \pm 9.28 \mathrm{a}$ & $118.18 \pm 19.39 \mathrm{a}$ \\
Triglycerides $\left(\mathrm{mg} \mathrm{dL}^{-1}\right)$ & $472.57 \pm 32.78 \mathrm{a}^{*}$ & $290.12 \pm 32.60 \mathrm{~b}^{*}$ & $306.28 \pm 63.60 \mathrm{~b}$ & $422.15 \pm 38.47 \mathrm{a}^{*}$ \\
\hline
\end{tabular}

Small different letters in the same row indicate statistically significant differences $(P<0.05)$ among essential oil inclusion levels; asterisk ( $\left.{ }^{\star}\right)$ indicates statistically significant differences $(P<0.05)$ between values before and after bacterial challenge. 
The tambaquis of the present study did not die during the experimental period and did not show any clinical signs of disease. According to Amirkhani and Firouzbaksh (2015), diets supplemented with ethanol extract of $O$. basilicum increased the resistance of $C$. carpio against infection by $A$. hydrophila, due to improvement of the nonspecific immune system. This was also observed in L. rohita fed with diets containing $M$. indica and challenged with $A$. hydrophila (Sahu et al. 2007). Ingestion of essential oil, such as from M. piperita, through diets, can be used as an immunostimulant, as reported for several species of plants and animals (Bairwa et al. 2012; Biller-Takahashi and Urbinati 2014; Mehana et al. 2015).

The increased hemoglobin concentration in the tambaquis fed with diets containing 0.5 and $1.5 \%$ of $M$. piperita essential oil could be related to an increase in oxygen supply, which promotes fish welfare. Similar results were found for L. calcarifer fed with diets containing $A$. sativum (Talpur and Ikhwanuddin 2012) and leaves of M. piperita (Talpur 2014). With the experimental bacterial infection, there was a decrease in $\mathrm{Hb}$ in the tambaqui fed with $1.5 \%$ of oil in the diet, due to the stress induced by the pathogen, as reported by Talpur and Ikhwanuddin (2012) in L. calcarifer. The $\mathrm{Hb}$ and $\mathrm{MCHC}$ of the tambaquis presented significant reductions after the challenge with $A$. hydrophila, consequently decreasing the $\mathrm{O}_{2}$ carrying capacity of the fish (Vijayan et al. 1997). In this study, it was also possible to observe a decrease in MCV after the bacterial challenge, among the fish fed with diets enriched with $1.0 \%$ of $M$. piperita essential oil, probably due to the tendency towards increased number of erythrocytes in the blood with the diet included $1.0 \%$ of the essential oil from $M$. piperita.

Feeding tambaquis with diets containing $M$. piperita did not cause stress in the fish, as indicated by the maintenance of plasma glucose at levels similar to those of the control group, even after application of the bacterial challenge with A. hydrophila. According to Talpur (2014), the inclusion of $M$. piperita stimulated insulin action, and therefore reduced glucose levels were also observed in $L$. calcarifer after feeding. Moreover, after the bacterial challenge, the glucose reduction could be attributed to fasting, consequent to the presence of the pathogen. Only after the bacterial challenge did the plasma protein concentration increase in the fish of the control group and in the fish fed with the diet containing $1.5 \%$ of M. piperita essential oil. Feeding fish with garlic (A. sativum), ginger (Zingiber officinale) and neem (Azadirachta indica) (Talpur and Ikhwanuddin 2012; 2013 a,b) increased protein concentration in L. calcarifer; and this was also reported to C. carpio fed with M. piperita extract (Abasali and Mohamad 2010). However, in tambaquis fed with M. piperita oil, plasma protein levels remained constant. Thus, exposure of the fish to stressful situations, such as the presence of pathogens, can result in a series of adjustments through homeostasis mechanisms (Almeida-Val et al. 2006).

Increased albumin levels in tambaqui plasma were observed only after the bacterial challenge in the fish fed with 0 and $1.0 \%$ inclusion of oil in the diet. Since plasma proteins include several humoral elements of the nonspecific immune system, this increase in albumin at the inclusion level of 1.0\% could reflect the increase in the nonspecific immune response of tambaqui. Sahu et al. (2007) reported similar results, since the protein levels (albumin and globulin levels) in young $L$. rohita fed with $M$. indica were greater than the levels of the control group.

The plasma cholesterol levels increased in all the tambaquis fed with $M$. piperita essential oil. After the bacterial challenge with $A$. hydrophila, there was only an increase in the control fish, which could indicate that the immunostimulant used may have provided a protective effect for the hepatic tissue of these fish, thus not causing serious dyslipidemia. The plasma triglyceride level decreased significantly in the tambaqui fed with $0.5 \%$ of $M$. piperita oil in the diet. After the bacterial challenge, the highest triglycerides levels were found in the fish fed with 0.5 and $1.5 \%$ of $M$. piperita oil. Unlike the present study, $L$. calcarifer fed with diets containing $M$. piperita showed reductions of total lipids, triglycerides and cholesterol (Talpur 2014).

\section{CONCLUSIONS}

The hematological and biochemical responses of tambaqui fed with diets supplemented with essential oil from $M$. piperita indicated that the oil had positive effects, due to plasma protein increases. The use of this essential oil can be recommended in diets for tambaquis at levels of up to $1.0 \%$ per $\mathrm{kg}$ of food for 30 days, because of the minimal physiological modifications that are caused. Nonetheless, additional studies using essential oil from $M$. piperita in diets for tambaquis over different feeding periods are necessary, in order to obtain information regarding to the physiological effects of this immunostimulant on these fish.

\section{ACKNOWLEDEGMENTS}

To E.C. Chagas for the donation of the essential oil from Mentha piperita. To the Brazilian Agricultural Research Corporation (Embrapa) and to the Fundaçáo de Amparo à Pesquisa do Estado do Amapá (FAPEAP - Grant number 250.203.063/2014) for the financial grants.

\section{REFERENCES}

Abasali, H.; Mohamad, S. 2010. Immune response of common carp (Cyprinus carpio) fed with herbal immunostimulants diets. Agricultural Journal, 5: 163-172. 
Almeida-Val, V.M.F.; Chippari-Gomes, A.R.; Lopes, N.P. 2006. Metabolic and physiological adjustments to low oxygen and high temperature in fishes of the Amazon. In: Val., A.L., Almeida-Val, V.M.F. and Randall, D.J. (Eds.), Fish Physiology, v. 21, Elsevier, Heildelberg, p. 443-500.

Amirkhani, N.; Firouzbaksh, F. 2015. Protective effects of basil (Ocimum basilicum) ethanolic extract supplementation diets against experimental Aeromonas hydrophila infection in common carp (Cyprinus carpio). Aquaculture Research, 46: 716-724.

Anderson, D.P. 1992. Immunostimulants, adjuvants, and vaccine carriers in fish: applications to aquaculture. Annual Review of Fish Diseases, 2: 281-307.

Bairwa, M.K.; Jakhar, J.K.; Satyanarayana, Y.; Reddy A.D. 2012. Animal and plant originated immunostimulants used in aquaculture. Journal of Natural Products Resources, 2: 397-400.

Biller-Takahashi, J.D.; Urbinati, E.C. 2014. Fish Immunology. The modification and manipulation of the innate immune system: Brazilian studies. Anais da Academia Brasileira de Ciências, 86: 75-87.

Citarasu, T. 2010. Herbal medicines: a new opportunity for aquaculture industry. Aquaculture International, 18: 403-414.

Dairiki, J.K., Majolo, C.; Chagas, E.C.; Chaves, F.C.M.; Oliveira, M.R.; Moraes, I.S. 2013. Procedimento para inclusão de óleos essenciais em raçóes para peixes. Circular Técnica, 42, Embrapa Amazônia Ocidental, Manaus, Amazonas, 8 p.

Harikrishnan R.; Balasundaram, C. 2008. In vitro and in vivo studies of the use of some medicinal herbals against fish pathogen Aeromonas hydrophila in goldfish. Journal of Aquatic Animal Health, 20: 165-176.

Harikrishnan, R.; Balasundaram, C.; Heo, M.-S. 2009b. Effect of chemotherapy, vaccines and immunostimulants on innate immunity of goldfish infected with Aeromonas hydrophila. Diseases of Aquatic Organisms, 88: 45-54.

Harikrishnan, R.; Balasundaram, C.; Kim, M.-C.; Kim, J.-S.; Han, Y.-T.; Heo, M.-S. 2009a. Innate immune response and disease resistance in Carassius auratus by triherbal solvent extracts. Fish \& Shellfish Immunology, 27: 508-515.

Izel, A.C.U.; Melo, L.A.S. 2004. Criaçâo de tambaqui (Colossoma macropomum) em tanques escavados no estado do Amazonas. Série Documentos, 32, Embrapa Amazônia Ocidental, Manaus, Amazonas, 19p.

Jagruthi, C.; Yogeshwari, G.; Anbazahan, S.M.; Mari, L.S.S.; Arockiaraj, J.; Mariappan, P.; et al. 2014. Effect of dietary astaxanthin against Aeromonas hydrophila infection in common carp, Cyprinus carpio. Fish \& Shellfish Immunology, 41: 674-680.

Joseph, S.W.; Carnahan, A. 1994. The isolation, identification, and systematics of the motile Aeromonas species. Annual Review of Fish Diseases, 4: 315-343.

Kaskhedikar, M.; Chhabra, D. 2010. Multiple drug resistance in Aeromonas hydrophila isolates of fish. Veterinary World, 3: 76-77.

Logambal, S.M.; Venkatalakshmi, S.; Michael, R.D. 2000. Immunostimulatory effect of leaf extract of Ocimum sanctum Linn. in Oreochromis mossambicus (Peters). Hydrobiologia, 430, 113-120.
Mehana, E.E.; Rahmani, A.H.; Aly, S.M. 2015. Immunostimulants and fish culture: an overview. Annual Research \& Review in Biology, 5; 477-489.

Monette, S.; Dallaire, A.D.; Mingelbier, M.; Groman, D.; Uhland, C.; Richard, J.-P.; et al. 2006. Massive mortality of common carp (Cyprinus carpio carpio) in the St. Lawrence River in 2001: diagnostic investigation and experimental induction of lymphocytic encephalitis. Veterinary Pathology, 43: 302-310.

Paniagua, C., Rivero, O., Anguita, J.; Naharro G. 1990. Pathogenicity factors and virulence for rainbow trout (Salmo gairdneri) of motile Aeromonas spp. isolated from a river. Journal of Clinical Microbiology, 28: 350-355.

Ranzani-Paiva, M.J.; Pádua, S.B; Tavares-Dias, M.; Egami, M. 2013. Métodos para análise hematológica em peixes. Eduem, Maringá, Paraná, 140p.

Sakai, M.1999. Current research status of fish immunostimulants. Aquaculture, 172, 63-92.

Sahu, S.; Das, B.K.; Pradhan, J.; Mohapatra, B.C.; Mishra, B.K.; Sarangi, N. 2007. Effect of Mangifera indica kernel as a feed additive on immunity and resistance to Aeromonas hydrophila in Labeo rohita fingerlings. Fish \& Shellfish Immunology, 23, 109-118.

Seshadri, R.; Joseph, S.W.; Chopra, A.K.; Sha, J.; Shaw, J.; Graf, J.; et al. 2006. Genome sequence of Aeromonas hydrophila ATCC 7966 ${ }^{\mathrm{T}}$ : Jack of all trades. Journal of Bacteriology, 88: 8272-8282.

Sharafi, S.M.; Rasooli, I.; Owlia, P.; Taghizadeh, M.; Astaneh, S.D.A. 2010. Protective effects of bioactive phytochemicals from Mentha piperita with multiple health potentials. Pharmacognosy Magazine, 6: 147-153.

Silva, B.C. da; Mouriño, J.L.P.; Vieira, F.N.; Jatobá, A., Seiffert, W.Q.; Martins, M.L. 2012 Haemorrhagic septicaemia in the hybrid surubim (Pseudoplatystoma corruscans $\times$ Pseudoplatystoma fasciatum) caused by Aeromonas hydrophila. Aquaculture Research, 43, 908-916.

Talpur, A.D. 2014. Mentha piperita (Peppermint) as feed additive enhanced growth performance, survival, immune response and disease resistance of Asian seabass, Lates calcarifer (Bloch) against Vibrio harveyi infection. Aquaculture, 420-421: 71-78.

Talpur, A.D., Ikhwanuddin, M. 2013b. Azadirachta indica (neem) leaf dietary effects on the immunity response and disease resistance of Asian seabass, Lates calcarifer challenged with Vibrio harveyi. Fish \& Shellfish Immunolology, 34: 254-264.

Talpur, A.D., Ikhwanuddin, M., 2013a. Nutritional effects of ginger (Zingiber officinale Roscoe) on immune response of Asian sea bass, Lates calcarifer (Bloch) and disease resistance against Vibrio harveyi. Aquaculture, 400-401: 46-52.

Talpur, A.D.; Ikhwanuddin, M. 2012. Dietary effects of garlic (Allium sativum) on haemato-immunological parameters, survival, growth, and disease resistance against Vibrio harveyi infection in Asian sea bass, Lates calcarifer (Bloch). Aquaculture, 364-365: 6-12.

Tavares-Dias, M. 2011. Piscicultura continental no Estado do Amapá: diagnóstico e perspectivas. Boletim de Pesquisa e Desenvolvimento, 81, Embrapa Amapá, Macapá, Amapá, 42p. 
Val, A.L.; Rolim, P.R.; Rabelo, H. 2000. Situação atual da aqüicultura na regiâo Norte. In: Aqüicultura no Brasil. Bases para um desenvolvimento sustentável. Valenti, W.C.; Poli, C.R.; Pereira, J.A.; Borghetti, J.R. (Eds.). CNPq, Brasília, DF, p. 247-266.

Vijayan, M.M.; Pereira, C.; Grau, E.G.; Iwama, G.K. 1997. Metabolic responses associated with confinement stress in tilapia: the role of cortisol. Comparative Biochemistry Physiology, 116C: 89-95.

Zar, J.H. 2010. Biostatistical analysis. $5^{\text {th }}$ ed. Prentice-Hall, New Jersey, 944p.

Recebido em 10/04/2015

Aceito em 20/07/2015 
